\title{
Effect of Fertilizer Manure and Lime on Growth and Yield of Boro Rice in Acidic Red Soil
}

\author{
Atiya Sharmin Mitu ${ }^{1}$, Md Asaduzzaman Khan ${ }^{2}$ and Md Rais Uddin Rashed ${ }^{3 *}$ \\ Department of Soil Science, Sher-e-Bangla Agricultural University, Bangladesh
}

Submission: March 07, 2017; Published: April 19, 2017

"Corresponding author: Md Rais Uddin Rashed, Department of Genetics and Plant Breeding, Sher-e-Bangla Agricultural University, Dhaka-1207, Bangladesh, Email: rurashed1987@gmail.com

Abstract

The experiment was conducted to evaluate the morpho-physiological, yield and yield potentialities of Boro rice along with change of nutrients and lime in rice grain as influenced by acidic red soil and different types of fertilizers. Two acidic red soils of Bhatgaon (S1) and Goari (S2) along with nine different fertilizer treatments viz. T0: Control, T1: N150P30K70S20Zn3 (Recommended dose of chemical fertilizer), T2: N150P30K70S20Zn3 (RDCF)+1.0g lime kg-1soil, T3: 50\% NPKS+5 ton cow dung ha-1, T4: 50\% NPKS+5 ton cow dung ha-1+1.0g lime kg1soil, T5: 50\% NPKS + 5 ton compost ha-1, T6: 50\% NPKS+5 ton compost ha-1+1.0g lime kg-1 soil, T7: 50\% NPKS+3.5 ton poultry manure ha- 1 and T8: $50 \%$ NPKS+3.5 ton poultry manure ha- $1+1.0 \mathrm{~g}$ lime $\mathrm{kg}-1$ soil were used for the study. The pore-water P concentration decreased with increasing days after transplantation of rice and higher levels of pore-water P concentrations were found in the inorganic plus manure and lime applied fertilizer treatments $(0.400 \mathrm{ppm})$. The pore-water $\mathrm{P}$ concentrations and other yield attributes were positive and strongly correlated with the grain and straw yields of rice.

In case of acidic soil, the soil of Bhatgaon had more efficient to produce more effective tillers (22.11) along with highest yield of grain (35.15g pot-1) and straw (54.37g pot-1) than the soil of Gorai. N, P, K and S content in Boro rice grain had also higher in Bhatgoan (1.316, $0.079,0.524$ and $0.119 \%$, respectively) than Gorai. Similarly, 50\% organic manure along with organic and lime application obtained the tallest plant $(70.42 \mathrm{~cm})$, longest panicle $(22.31 \mathrm{~cm})$, more filled grains panicle-1 $(74.83 \mathrm{~cm})$ and greater production of Boro rice $(41.67 \mathrm{~g}$ pot-1) compared $100 \%$ recommended dose of NPKSZn. N, P, K and S content in rice grain were also statistically significant due to different fertilizer treatments while $50 \%$ NPKS+3.5 ton poultry manure ha-1+1.0g lime kg-1 soil showed significant and higher levels of NPKS $(1.902,0.070$ 0.538 and $0.169 \%$, respectively) than that of other treatments of the study. However, all the studied characters except productive tillers hill- 1 were not statistically significant.

Keywords: Agro-ecological zones (AEZ); Effective tillers; Acidic red soil

\section{Introduction}

Toxicity of aluminum and manganese is the most important growth limiting factor in many acid soils. Besides this, the reduced uptake of calcium and magnesium in the soil solution can also be alleviated with the application of lime. The application of liming materials to such soils will inactivate the iron and aluminum, thus increasing the level of plant available phosphorus and other macronutrient. A number of long-term field trials have observed soil acidification where residues have been retained Paul et al. [1], $\mathrm{Xu}$ et al. [2], which was largely due to high soil N status. Increasing Ca concentration in the nutrient solution and liming had a beneficial effect on plant growth under $\mathrm{Al}$ stress and alleviated $\mathrm{Al}$ toxicity of plants Shen et al. [3].

Nayak et al. [4] reported that application of compost and inorganic fertilizer increased microbial growth in soil, vegetative growth and maximum tillering of rice. Xu et al. [5] observed that application of half inorganic fertilizer and half organic manure increase nutrient absorption, panicle number, and yield of rice \& also increased soil organic matter. Namibiar [6] observed that integrated use of organic manure and chemical fertilizers would be quite promising not only in providing greater yield but also to maintain better soil fertility. Balanced fertilization and complementary use of inorganic fertilizers with FYM, cow dung, poultry litter, sugar mill waste (press mud) and other wastes will go a long way in both improving the yield as well as improving the soil quality Aulakh et al. [7].

To increase the efficiency of manure and fertilizer in acidic soil rice cultivation, it is necessary to identify the suitable combination of manure and fertilizer with or without lime. Poultry manure, 
cowdung, compost and lime will be used for increasing crop yield, maintaining fertility of the soils and ameliorating the acidity of soils. It is necessary to identify the suitable manure for increasing the soil $\mathrm{pH}$, fertility and productivity of acidic soils. The present study was conducted to investigate the effects of manure (organic) and fertilizer (inorganic) with or without lime on the growth, yield and nutrient availability in postharvest soil. Considering the above facts, the present research study was therefore undertaken to find out following objectives:

A. To investigate the effects of acidic red soil on productivity of Boro rice.

B. To determine the role of fertilizer and manure with or without lime in relation to the above aspect.

C. To identify the suitable combination(s) of fertilizer and manure with or without lime.

D. To select the most advantageous interaction.

\section{Materials and Methods}

The experiment was conducted at the net house of the Department of Soil Science, Sher-e-Bangla Agricultural University (SAU), Dhaka-1207, during the Boro season.

\section{Soil details}

Two different acidic soils were collected from Bhatgaon and Goari under Bhaluka Upazilla, Mymensingh belongs to the AEZ No. 28, Madhupur Tract, classified as Deep Red Brown Terrace Soils in Bangladesh soil classification system. A sampling device (Rhizon MOM $10 \mathrm{~cm}$ length, $2.5 \mathrm{~mm}$ OD, Rhizosphere Research Products, Wageningen, and The Netherlands) was buried diagonally in the middle of the soil of each pot for collecting soil solution. The texture of soil-1 was silt loam having $\mathrm{pH} 5.4$ and contains organic matter $0.62 \%$, total $\mathrm{N} 0.08 \%$, available P $3.6 \mathrm{ppm}$, available K $0.08 \mathrm{meq}$ $100 \mathrm{~g}-1$. The soil-2 texture was silt loam having pH 5.5 and contains organic matter $0.52 \%$, total N $0.08 \%$, available P $1.10 \mathrm{ppm}$, available K 0.083meq 100g-1.

\section{Different types of fertilizer and manure treatments (8)}

Three types of organic manure (cow dung, compost and poultry manure) were used in this rice experiment. There was nine fertilizer or manure with and without lime treatments, namely

i. T0: Control

ii. T1: N150P30K70S20Zn3 (Recommended dose of chemical fertilizer)

iii. T2: N150P30K70S20Zn3 (RDCF)+1.0 g lime (dolomite) kg-1 soil (2 ton ha-1)

iv. T3: $50 \%$ NPKSZn+5 ton cowdung ha-1

v. T4: 50\% NPKSZn+5 ton cowdung ha-1+1.0 g lime kg-1 soil (2 ton ha-1)

vi. T5: 50\% NPKSZn+5 ton compost ha-1 vii. T6: $50 \%$ NPKSZn+5 ton compost ha- $1+1.0 \mathrm{~g}$ lime $\mathrm{kg}-1$ soil (2 ton ha-1)

viii. T7: 50\% NPKSZn+3.5 ton poultry manure ha-1 and

ix. T8: $50 \%$ NPKSZn+3.5 ton poultry manure ha-1+1.0 g lime $\mathrm{kg}-1$ soil (2 ton ha-1)

There were on the whole $18(2 \times 9)$ treatments combination as S1T0, S1T1, S1T2, S1T3, S1T4, S1T5, S1T6, S1T7, S1T8, S1T9, S2T0, S2T1, S2T2, S2T3, S2T4, S2T5, S2T6, S2T7, S2T8 and S2T9.

\section{Cultivation of crops}

Seed collection: Healthy and vigorous seeds of BRRI dhan-29 were used in this experiment which was collected from Bangladesh Rice Research Institute (BRRI).

Seed sprouting: The selected seeds were soaked for 24 hours and then these were kept in gunny bags. The seed started sprouting after 48 hours and almost all seeds were sprouted after 72 hours.

Preparation of seedling tray and seed sowing: Two of each $24 \times 12 \times 6$ inches tray (length, width and depth, respectively) were selected for sowing the sprouting seeds.

Preparation of experimental pot: There were 54 earthen pots of each ( 9 fertilizer treatments $\mathrm{x} 2$ soils $\mathrm{x} 3$ replications) were used for the experiment where the sizes of each pot was (18" height x16" diameter). The collected experimental $756 \mathrm{~kg}$ soil from the two villages (378kg for each village) of Bhaluka Upazilla was kept in the net house and the pieces of soil were broken down by khurpi. Later on those soils were properly mixed with fertilizer(s) as per treatments of the study where the RDCF of NPKSZn was used as fertilizer recommendation guide of BARC (2012). One week later, the fertilizer treated soil was kept in experimental pot while $14 \mathrm{~kg}$ treated soil were used in each pot.

\section{Application of fertilizers}

The required amount of dolomite was applied at the rate of 2 ton ha- 1 . The water management was continuous flooding $(2-3 \mathrm{~cm}$ water) during the growing period of rice. The required amount of manures (N150P30K70S20Zn3), TSP, MP, gypsum, zinc sulphate and one third ureas were applied during the final soil preparation by considering the fertilizer treatments and weight of soil in the pot.

\section{Soil and crop sampling for data collection}

A sampling device (Rhizon MOM $10 \mathrm{~cm}$ length, $2.5 \mathrm{~mm}$ OD, Rhizosphere Research Products, Wageningen, Netherlands) was buried diagonally in the middle of the soil of each pot for collecting soil solution. Soil pore-water samples were collected for each crop at 30 and 60 days after transplantation of rice and analyzed for $\mathrm{pH}, \mathrm{N}$, $\mathrm{P}$ and $\mathrm{K}$ contents. Grain and straw yields were recorded separately pot-wise and moisture percentage was calculated after sun drying.

\section{Collection and preparation of plant samples}

The plant samples were dried in an oven at $70 \mathrm{C}$ for 72 hours and then ground by a grinding machine (wiley-mill) to pass through a 20-mesh sieve. 


\section{Statistical analysis}

Analysis of variance was done with the help of MSTAT-C computer package programme developed by Russel (1986). The mean differences among treatment were tested with Duncan's Multiple Range Test at 5\% level of probability (Gomez and Gomez, 1984).

\section{Results and Discussion}

\section{Effect of regional acidic soil on the pore water $P$ concentration}

The higher levels of pore-water $\mathrm{P}(0.180 \mathrm{ppm})$ was found in soil of Goari (S2) compared (0.131ppm) to the soil of Bhatgaon (S1) at 30 DAT. In contrast, the availability of $P$ concentrations of the collected pore water of Bhatgaon and Goari were 0.016 and $0.012 \mathrm{ppm}$, respectively where Bhatgaon showed higher $\mathrm{P}$ concentration than Goari. However, obtained result of both regional acidic soils showed decreased tendency from 30 DAT to 60 DAT during Boro rice cultivation (Figure1).

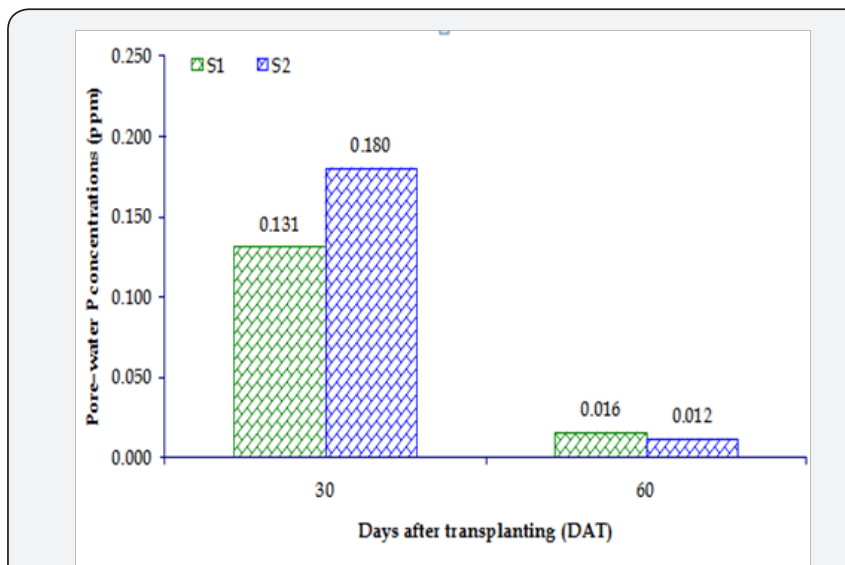

Figure 1: Effect of regional acidic soil on pore-water Phosphorus concentrations at different days after transplanting of Boro rice.

Effect of different types of fertilizers on the pore water $P$ concentration

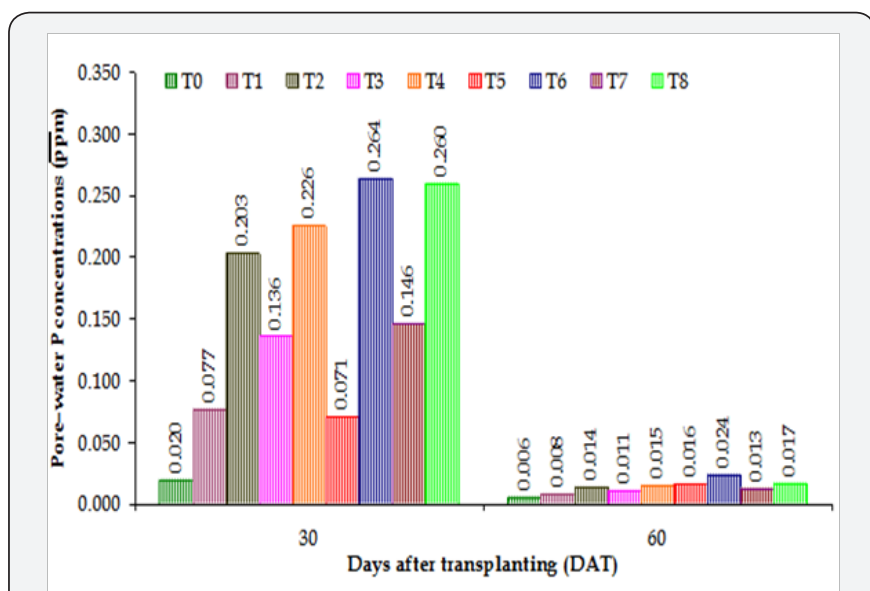

Figure 2: Effect of different types of fertilizers on pore-water Phosphorus concentrations at different days after transplanting of Boro rice.
The higher levels of pore-water P concentrations $(0.264 \mathrm{ppm})$ were found at 30 DAT (Figure 2) in fertilizer treatments where $50 \%$ RDCF were used in mixed with 5 ton compost ha-1 and 1.0 g lime kg-1 soil or 2 ton lime ha-1 (T6). Almost similar level of $\mathrm{P}$ concentration $(0.260 \mathrm{ppm})$ was found in the lime applied treatment T8 (50\% NPKS+3.5 ton poultry manure ha-1+1.0g Lime kg-1 soil or 2 ton lime ha-1) while lowest $\mathrm{P}$ concentration $(0.020 \mathrm{ppm})$ was found in T0 treatment where fertilizer was not applied. Lower levels of pore-water $\mathrm{P}$ concentrations were found at 60 DAT with average ranges of 0.006 (To) to $0.024 \mathrm{ppm}$ (T6).

\section{Interaction effects of regional acidic soil and different types of fertilizers}

However, the interaction effect of regional acidic soil and fertilizer was significantly influenced the pore-water Phosphorus concentrations at 30 DAT but the P concentrations of the porewater at 60 DAT did not differed significantly. Obtained result from the Table 1 it was found that the pore-water P concentrations gradually decreased from 30 DAT to 60 DAT due to whole interaction treatments. The pore-water $\mathrm{P}$ concentrations varied from 0.005 (S1T0) to 0.032ppm (S1T6) at 60 DAT due to different treatments of interaction but whole treatments were statistically more or less similar due to non significant difference. At 30 DAT, the highest pore-water P concentration $(0.400 \mathrm{ppm})$ was found from the soil of Goari treated by $50 \%$ RDCF along with 5 ton cow dung tha- $1+1.0 \mathrm{~g}$ lime kg-1 soil or 2 ton lime ha- 1 (S2T4) followed by $(0.380 \mathrm{ppm})$ the same soil treated by $50 \%$ RDCF along with 5 ton cow dung tha- $1+$ 1.0g lime kg-1 soil or 2 ton lime ha-1 (S2T6). The without fertilizer treated soil of Bhatgaon (S1T0) showed the lowest pore-water P concentration $(0.004 \mathrm{ppm})$ in the present study (Table 1$)$.

Table 1: Effects of acidic red soil types on N, P, K and S content in Boro rice grain.

\begin{tabular}{|c|c|c|c|c|}
\hline Soil & $\mathbf{N}(\mathbf{\%})$ & $\mathbf{P}(\%)$ & $\mathbf{K}(\%)$ & $\mathbf{S}(\%)$ \\
\hline S1 & $1.316 \mathrm{a}$ & $0.079 \mathrm{a}$ & $0.524 \mathrm{a}$ & $0.119 \mathrm{a}$ \\
\hline $\mathrm{S} 2$ & $1.246 \mathrm{~b}$ & $0.038 \mathrm{~b}$ & $0.407 \mathrm{~b}$ & $0.115 \mathrm{~b}$ \\
\hline $\mathrm{SE}( \pm)$ & 0.0605 & 0.0055 & 0.0247 & 0.0055 \\
\hline
\end{tabular}

\section{Effect of different types of fertilizers}

Effect of different types of fertilizer significantly influenced the N, P, K and S content of boro rice grain while 50\% NPKS+3.5 ton poultry manure ha- $1+1.0 \mathrm{~g}$ lime $\mathrm{kg}-1$ soil (T8) was the best treatment for getting the higher nutrient content in boro rice grain ( Table 1).

In a column figures having similar letter(s) do not differ significantly at $5 \%$ level whereas figures with dissimilar letter(s) differ significantly as per DMRT

\section{Correlation and regression studies}

Grain yield and pore-water $\mathbf{P}$ concentrations: The relationship between grain yield and pore-water $P$ concentrations at 30 DAT has been found out. The correlation co-efficient ( $\mathrm{r} 2=0.4619$ ) was found positive significant correlation. The line of regression of $\mathrm{Y}$ (grain yield) on X (pore-water P concentration) having equation 
$Y=7.4275 \operatorname{Ln}(X)+49.533$ is shown in Figure 3. The positive slope indicates that the grain yield and pore-water $\mathrm{P}$ concentration are directly correlated i.e., increase in pore water $\mathrm{P}$ concentration in an increase in grain yield of rice.

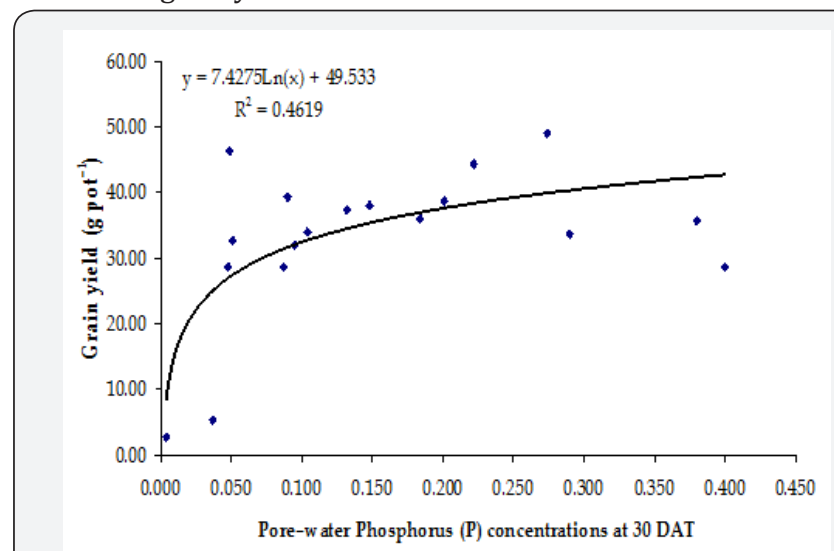

Figure 3: Relationship between pore-water $\mathrm{P}$ concentration and grain yield of rice.

Grain yield and plant height: The relationship between grain yield and plant height has been found out. The correlation coefficient ( $\mathrm{r} 2=0.8044$ ) was found positive significant correlation. The line of regression of $Y$ (grain yield) on X (plant height) having equation $\mathrm{Y}=132.9 \mathrm{Lm}(\mathrm{x})-524.17$ is shown in Figure 4. The positive slope indicates that the grain yield and plant height are directly correlated i.e., increase in plant height in an increase in grain yield of rice.

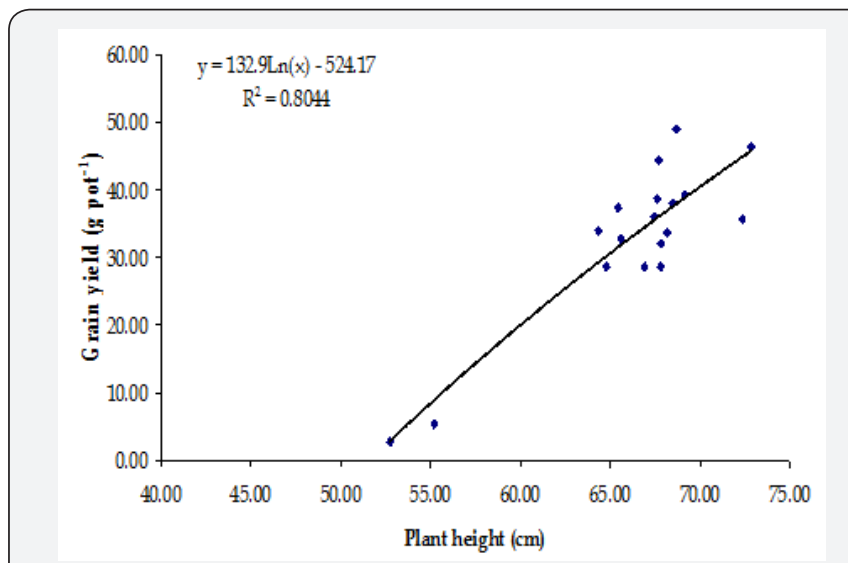

Figure 4: Relationship between grain yield and plant height of rice.

Grain yield and number of effective tillers hill-1: The relationship between grain yield and number of effective tillers hill- 1 has been found out in Figure 5 and the correlation co-efficient ( $r 2=0.9097$ ) value showed positive significant correlation between them. The line of regression of $Y$ (grain yield) on $X$ (number of effective tillers hill-1) having equation $\mathrm{Y}=22.765 \operatorname{Ln}(\mathrm{x})-33.673$ is shown in Figure 5. From the 05, it was found the slope represent positive correlation between grain yield and number of effective tillers hill-1. These results indicated that the both characters are directly correlated i.e. increase in number of effective tillers hill-1 in an increase in grain yield of rice.
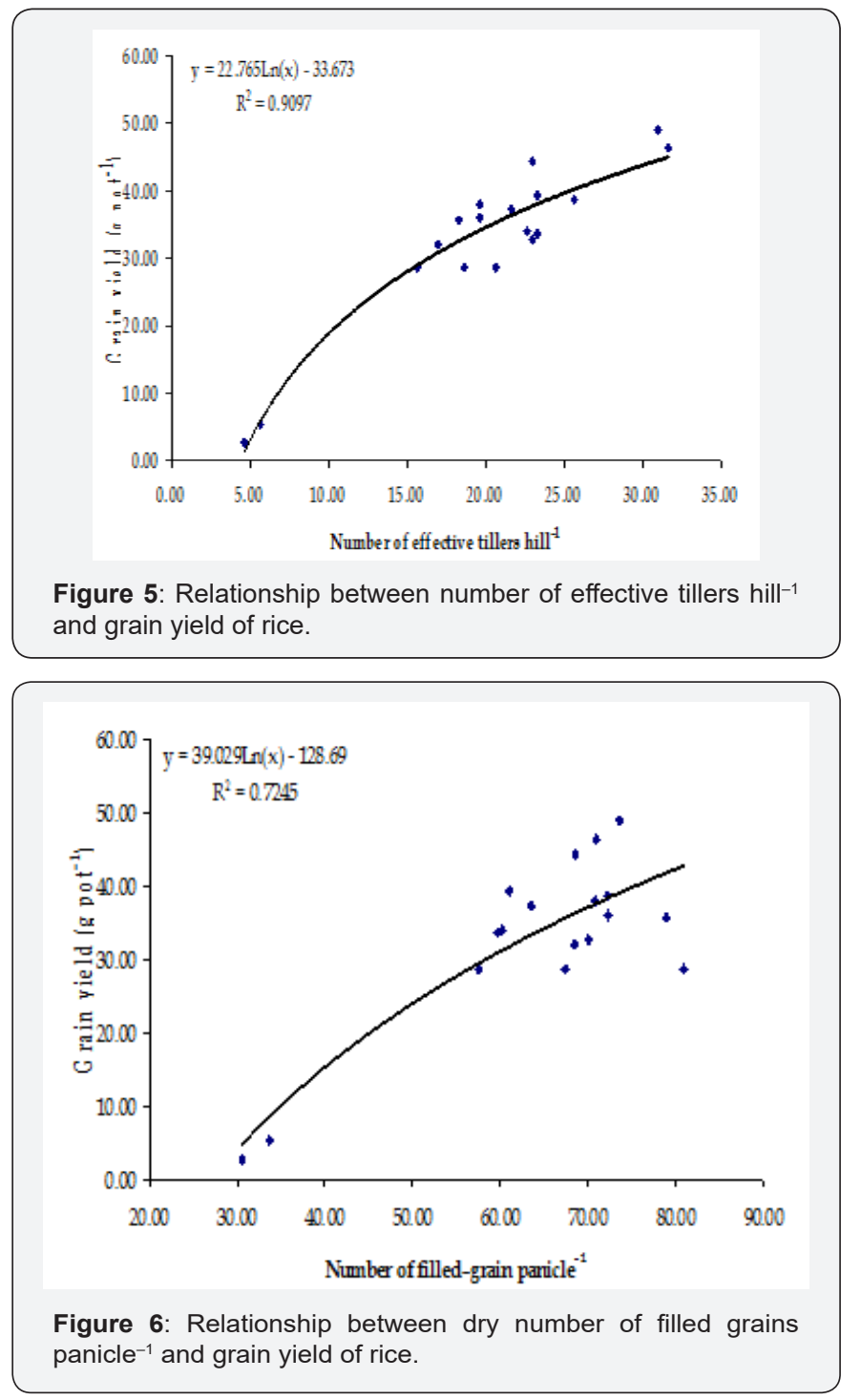

Grain yield and number of filled grains panicle-1: From the line of regression Figure 6 it was found that there was positive significant correlation between the number of filled grains panicle- 1 and grain yield. The correlation co-efficient ( $\mathrm{r} 2=0.7245$ ) value proved positive significant correlation between them. The line of regression of $Y$ (grain yield) on X (filled grains panicle-1) having equation $Y=39.029 \operatorname{Ln}(x)-128.69$ is shown in Fig. 06. From the 06, it was found the slope represent positive correlation between grain yield and number of filled grains. These results indicated that the both characters are directly correlated i.e. increase in number of filled grains panicle- 1 in an increase in grain yield of rice.

Thousand grain weight and grain yield: The relationship between thousand grain weight and grain yield has been presented in Figure 7. The correlation co-efficient value of them are $\mathrm{r} 2=0.3568$. The line of regression of $\mathrm{Y}$ (Grain yield) on $\mathrm{X}$ (thousand grain weight) having equation $\mathrm{Y}=77.906 \operatorname{Ln}(\mathrm{x})-199.62$ is shown in Figure 7. The positive slope indicates that the grain yield and thousand grain weight are directly correlated i.e., increase in thousand grain weight in an increase in grain yield of rice. 


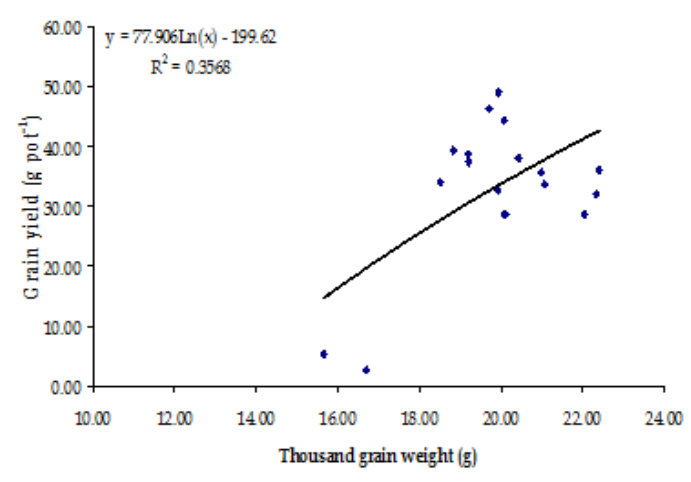

Figure 7: Relationship between thousand grain weight and grain yield of rice.

Straw yield and grain yield: The relationship between straw yield and grain yield has been found out. The correlation co-efficient biological yield and grain yield (r2=0.8743) was found significant. The line of regression of $Y$ (grain yield) on $X$ (straw yield) having equation $\mathrm{Y}=16.831 \mathrm{Ln}(\mathrm{x})-30.392$ is shown in Figure 8. The positive slope indicates that the straw yield and grain yield are directly correlated i.e., increase in straw yield in an increase in grain yield of rice.

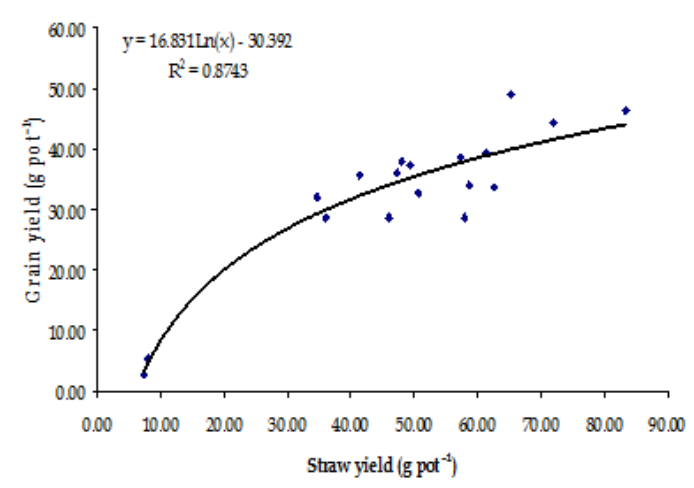

Figure 8: Relationship between straw and grain yield of rice.

The present study was conducted to identify the most optimum levels of mixed organic manures(s) and inorganic fertilizer along with or without lime for getting the more production of rice by enhancing the soil fertility status of postharvest soil under acidic red paddy soil through organic amendments. It will also enhance the farmer knowledge for extending the rice production under the AEZ-28 and developed sustainable agriculture. For aiming this point, nine different fertilizer and manure treatments along with or without lime were used for evaluated the productivity of rice and pore-water $\mathrm{P}$ concentration along with the status of postharvest soil fertility of two regional acidic red soil. Considering the aim of the study, the overall discussion on the result with some interpretations are mentioned below:

\section{Pore water}

From the observing result of pore-water $\mathrm{P}$ concentrations, it was found that the Pore-water P concentrations were decreased in all the treatments with increasing time. The effect of different types of fertilizer and manure had highly significant on porewater $\mathrm{P}$ concentration while it was the highest in the treatment where fertilizer, manure and lime were applied together. This was found might be due their conjugal application increased the macro and micro nutrient to the soil which ultimately enhances the $\mathrm{P}$ concentration in soil pore-water.

\section{Soil fertility status of postharvest soil}

Results revealed that the 50\% NPKS along with organic manure in present of lime had more effective for soil fertility. This was found might be due to the effect of lime on acid soil man enhance the activities of beneficial microbes in the root zone and brings several chemical and biological changes in the soil which are beneficial or helpful in improving the crop.

\section{Correlation and regression studies}

All the line of regression of $Y$ was grain yield and $X$ was other characters where their positive slope indicated that the grain yield increased significantly with the increasing selected relationship other characters. This result indicated that organic and inorganic based fertilizer along with lime had more influential effect on grain. Similarly, Gitari et al. [8] also found that linear correlation analyses showed that the treatment of lime and manure had the best for maize yield along with highest root length, plant height and dry biomass weight obtained.

\section{Conclusion}

The pore-water $\mathrm{P}$ concentrations decreased with increasing days after transplantation. Higher concentrations of pore-water $\mathrm{P}$ were found in the organic plus inorganic fertilizer and lime applied treatments. There was a significantand positive correlation observed between pore-water $\mathrm{P}$ concentrations and rice yields. Besides, most of the yield attributes were also positively correlated with grain yield of the present study. The higher morpho-physiological development of rice along with greater production was obtained in the collected soil of Bhatgaon compared Goari.

The higher grain yields of boro rice were produced from T2 (41.67) where dolomite was applied with RDCF fertilizer. However, most of the characters did not vary significant due to the interaction effects but the highest Boro rice yield (49.33g pot-1) was obtained in S1T2 (Bhatgoan Soil+RDCF+1.0g. lime kg-1 soil) where lime was applied with RDCF. The highest yield obtained from S1T2 which was statistically similar with S2T8 (Gouri+50\%NPKS+3.5 ton poultry manure ha- $1+1.0 \mathrm{~g}$ lime $\lg -1$ soil) S1T8 (Bhatgoan Soil+3.5 ton poultry manure ha-1+1.0g lime lg-1 soil).

Application of inorganic fertilizer plus manure and lime for rice cultivation significantly increased the grain nutrient level. The level of $\mathrm{P}$ and $\mathrm{S}$ in rice grain increased more with the application of inorganic fertilizer + lime due to cow dung and poultry manure, respectively. From the above concluding remarks of the present study it could be suggested that the farmer(s) of our country can be applied organic manure or lime along with 50\% NPKS for 
enhancing the production of boro rice in acidic red soil. Also, this result may create the opportunity for sustainable agriculture of safer production. Adding more types of soil and more other different levels of organic and inorganic mixed fertilizer may be needed to include for further study to make sure the findings in different agroecological zones (AEZ) of Bangladesh.

\section{Acknowledgement}

I am grateful to all members of the soil science department of Sher-e-Bangla Agricultural University, Dhaka, Bangladesh.

\section{References}

1. Paul KI, Black AS, Conyers MK (2001) Influence of fallow, wheat and subterranean clover on $\mathrm{pH}$ within an initially mixed surface soil in the field. Biological and Fertility of Soils 33(1): 41-52.

2. Xu RK, Coventry DR, Farhoodi A, Schultz JE (2002) Soil acidification as influenced by crop rotations, stubble management, and application of nitrogenous fertiliser, Tarlee, South Australia. Australian Journal of Soil and Research 40(3): 483-496.
3. Shen ZG, Wang JL, Guan HY (1993) Effect of aluminum and calcium on growth of wheat seedlings and germination of seeds. Journal of Plant Nutrition 16(11): 2135-2148.

4. Nayak DR, Jagadeesh Y, Babub, Adhya TK (2007) Long-term application of compost influences microbial biomass and enzyme activities in a tropical Aeric Endoaquept planted to rice under flooded condition. Soil Biology and Biochemistry 39(2007): 1897-1906.

5. Xu K, Lei Y, Choi JK (2008) Kiitricha minuta n. sp, a peculiar hypotrichous ciliate (Ciliophora, Spirotrichea) from the Yellow Sea. Journal of Eukaryot Microbiology 55(3): 201-206.

6. Nambiar KKM (1991) Wheat for the nontraditional warm areas. Proceedings International Conference, Mexico, CIMMYT 5: 16-521.

7. Aulakh (2001) Research Integrated Nutrient Management in Rice. Agri. Yellow Pages Resources (Fertilizers).

8. Gitari HI, Mochoge BE, Danga BO (2015): Effect of lime and goat manure on soil acidity and maize (Zea mays) growth parameters at Kavutiri, Embu County- Central Kenya. Journal of Soil Science and Environmental Management 6(10): 275-283.

\section{Your next submission with Juniper Publishers will reach you the below assets}

- Quality Editorial service

- Swift Peer Review

- Reprints availability

- E-prints Service

- Manuscript Podcast for convenient understanding

- Global attainment for your research

- Manuscript accessibility in different formats

( Pdf, E-pub, Full Text, Audio)

- Unceasing customer service

Track the below URL for one-step submission

https://juniperpublishers.com/online-submission.php 